DOI 10.37882/2223-2982.2021.08.38

\title{
НОМЕНКЛАТУРА СРЕДСТВ ВЫРАЖЕНИЯ СЕМАНТИЧЕСКОГО СУБЪЕКТА ВО ФРАНЦУЗСКИХ ФРАЗЕОЛОГИЗМАХ ${ }^{1}$
}

\section{THE RANGE OF MEANS OF EXPRESSING A SEMANTIC SUBJECT IN FRENCH PHRASEOLOGICAL UNITS}

A. Chervony

Summary: The article focuses on the analysis of the range of the means of expression of the semantic subject in French phraseological units. In the article, special attention was paid to the indirect expression of the semantic subject by phraseological units. The article analyses the images inherent in the French language consciousness when nominating a semantic subject, identifies the ways of its indirect designation, defines and differentiates the connotation inherent in a particular phraseological unit of the French language. The formation of an indirect, phraseological expression of the subject is based on the processes of metaphorization and metonymization.

Keywords: phraseology, a semantic subject, the range, metonymy, metaphor, connotation.

\author{
Червоный Александр Михайлович \\ Д. филол. н., доцент, Таганрогский институт \\ имени А.П. Чехова (филиал) ФГБОУ ВПО «РГЭУ (РИНХ)» \\ ckutrik@yandex.ru
}

Аннотация: Статья посвящена рассмотрению номенклатуры средств выражения семантического субъекта во французских фразеологизмах. В работе особое внимание было обращено на косвенное выражение фразеологизмами семантического субъекта.

В статье были рассмотрены образы, присущие французскому языковому сознанию при номинации семантического субъекта, выявлены способы его косвенного обозначения, определена и дифференцирована коннотация, присущая той или иной фразеологической единице французского языка. В основе образования косвенного, фразеологического выражения субъекта лежат процессы метафоризации и метонимизации.

Ключевые слова: фразеологизм, семантический субъект, номенклатура, метонимия, метафора, коннотация.
K ак известно, фразеологизм - это устойчивое сочетание двух и более слов, хотя бы одно из которых претерпело семантические трансформации. Фразеологизм имеет цельное значение и в речи воспроизводится без изменений $[2$, с. 137; 4]. Фразеологизмы являются элементом культуры, они украшают нашу речь, делают ее образной, яркой, колоритной, национально окрашенной.

Фразеологические единицы служат для выражения действий, состояний, признаков предмета, образа и способа действия, понятий пространства и времени и т.д., они используются для выражения коннотативного и ироничного отношения говорящего к объекту своего высказывания.

Однако фразеологические единицы французского языка, как и русского, английского и немецкого языков служат в первую очередь для выражения семантического субъекта [7, с. 413], под которым мы понимаем разумную, активную, чувствующую, обладающую речемыслительными способностями субстанцию, планирующую, каузирующую и выполняющую некое действие в процессе своей жизнедеятельности - человека.

Семантический субъект во фразеологическом выражении может получать самую разнообразную номинацию. Номенклатура средств фразеологического выражения семантического субъекта включает в себя как прямое обозначение субъекта homme bronzé - бесстрашный, испытанный, закаленный боеи; homme fait - взрослый человек; homme (fort) serré - скряга, прижимистый человек, так и косвенное - lion du jour - герой дня; un vilain oiseau - противный субъект; un vieux tableau - немолодая, сильно накрашенная женшина и т.д. [3].

В настоящей работе особое внимание нами было обращено на косвенное выражение субъекта, что, собственно говоря, и отличает в первую очередь фразеологическое выражение человека от его нефразеологической номинации.

В статье были рассмотрены образы, присущие фран-

Исследование выполнено при финансовой поддержке Российского фонда фундаментальных исследований (РФФИ) в рамках научного проекта № 19-012-00062 «Полифония семантического субъекта (на материале русского, французского, английского и немецкого языков)», проводимого в ФГБОУ ВО «РГЭУ (РИНХ)»; руководитель - доктор филол. наук, доцент, заведующий кафедрой немецкого и французского языков А.М. Червоный 
цузскому языковому сознанию при номинации семантического субъекта, выявлены способы его косвенного обозначения, определена и дифференцирована коннотация, присущая той или иной фразеологической единице французского языка.

Французскими фразеологизмами данной группы передается как положительная / отрицательная коннотация, так и коннотация нейтральная или скорее коннотация неопределенная, значение которой определяется контекстом либо ситуацией.

Метонимическое обозначение семантического субъекта осуществляется при замене целого его частью, в нашем случае, при выражении субъекта его частью тела, т.е. выражением синекдохой.

\section{І. Части тела}

\section{Положительная коннотачия}

Образ сердиа является олицетворением семантического субъекта, положительные черты которого переданы аксиологически позитивными определениями мужественный, добрый, стальной.

1. Coeur d'acier - стальной человек;

2. Coeur de lion - мужественный человек;

3. C'est un coeur d'or - он очень добр, у него золотое сердие [3].

Отрицательную коннотацию фразеологизму Coeur double - притворщик, лицемер придает детерминатив double - двойной, в данном фразеологическом контексте выражающий значение неискренний.

\section{Отришательная коннотация}

Семантический субъект может быть наименован субстантивами - соматизмами, обозначающими органы речи - рот, глотка, верхняя конечность человека - рука, нижняя часть тела - зад субъекта и т.д. Негативную коннотацию фразеологическим оборотам, как указывалось выше, придают детерминативы: blanc в значении - незрелый; d'éponge - от французского существительного éponge (f) - губка; percé - лопнутый, порванный и т.д.

Например:

1. Вlanc bec-желторотый птенеи, молокосос;

2. La bouche parle de l'abondance de coeur (de l'abondance de coeur la bouche parle) - om избытка чувств развязывается язык, болтун;

3. Gosier d'éponge-пьяница;

4. C'est la basse continue de son discours - он вечно говорит об этом. Это не сходит у него с языка;

5. Les coudes percés - голодранцы;
6. C'est un cul de plomb-он все штаны просидит, тяжелый на подъем [3].

\section{Нейтральная конноташия}

Французский язык обладает коннотативно нейтральными фразеологизмами, в которых соматизмы в сочетании с определениями, выражают возраст субъекта, его физическое состояние, род занятий, профессию.

1. Menton bleu - зрелый муж, мужчина в летах;

2. Culblanc-лоточник;

3. Son corps est un brasier - у него сильная лихорадка, он весь горит;

4. C'est un corps de fer - у него железное здоровье, он силен как бык [3].

В третьем примере выразителем субъекта является притяжательное прилагательное мужского рода единственного числа son. В последнем примере субъект представлен интегрально, он обозначен всей своей телесной оболочкой - всем телом.

\section{II. Предметы неживой природы}

Довольно часто во французских фразеологизмах человек может быть наименован предметами неживой природы. Номенклатуру выражения субъекта составили фразеологические единицы, имеющие в своей структуре лексемы, выражающие элементы одежды, домашнюю утварь (посуду), продукты питания, различные изделия, приборы, устройства, орудия, вещество, предметы мебели, элементы жилища, помещение, представителей животного и растительного мира, абстрактные понятия и т.д.

\section{1. Одежка, обувь}

Конннотативно нейтральные фразеологические сочетания с лексемой col (m) - воротник выражают сам субъект, его род и профессию.

1. Colblanc - служаший;

2. Colbleu-военный моряк [3].

Фразеологическими сочетаниями с французским существительным bas (m) выражается негативная коннотация по отношению к субъекту.

1. Ваs bleu - синий чулок;

2. Ваs percé-голодранец [3].

Кроме того, данным фразеологическим единицам свойственно выражать гендерный аспект субъекта. Сuним чулком, как известно, называют невзрачную, лишенную обаяния, зацикленную на своей работе или научной деятельности женщину.

Образность приведенных ниже фразеологических 
сочетаний создается лексемами, обозначающими разные виды обуви chausson (m) - тапочка, туфля; galoche (f) - кожаный башмак на деревянной подошве.

Данные фразеологизмы выносят пейоративную характеристику представителям женского пола.

1. Vieux chausson - nomaскуха;

2. Une vieille galoche-старая галоша, развалина [3].

\section{2. Посуда, утварь}

Семантический субъект выражен метонимически при его обозначении лексемами, выражающими посуду, кухонную утварь.

\section{Например:}

1. C'est une bonne fourchette (J. Anouilh, "L'hurluberlu ou le réactionnaire») - Он большой гурман [3]. Субъект может быть представлен имплицтно, т.е. он формально не выражен, но на семантическом уровне подразумевается [6]. Маркером субъекта в данном случае выступает предмет, используемый для приготовления пищи marmite (f) - котелок, чугунок.

2. La marmite est renversée разг. - в доме ничего не готовят, приходится обедать вне дома;

3. La marmite est bonne dans cette maison - в этом доме хорошо едят, хорошо угощают, хороший стол [3].

\section{3. ИзАелия, приборы, устройства, орудия}

Фразеологизмы, включающие в свой состав лексемы, выражающие рукотворные предметы, обозначают семантический субъект косвенным образом - метонимически или метафорически [1, с. 11-16; 5, с. 103-129].

При этом они могут выносить как позитивную, так и негативную оценку субъекту.

Метонимический способ выражения субъекта. Негативная коннотация, выражаемая фразеологизмом:

1. Ses lunettes sont troubles - он неправильно смотрит на это, он неправильно судит об этом.

Метафорический способ выражения субъекта.

а) Фразеологизмы, содержащие позитивное отношение к семантическому субъекту.

1. Cordon bleu - человек с большими заслугами, кавалер ордена Святого духа, искусная кухарка;

2. Barre de fer-твердый человек [3].

б) Фразеологизмы, выражающие негативное отношение к семантическому субъекту.

1. Baton épineux (merdeux) - неприветливый, необщительный человек, брюзга, ворчун;
2. Baton flottant - нерешительный человек;

3. C'est une bassinoire - ну и нудный человек [3].

\section{4. Продукты питания}

Коллективный субъект метафорически представлен фразеологизмом, содержащим лексему crème $(f)$ - сливки. Этот субстантив выносит наивысшую оценку качеству человеческого материала.

- La crème de la crème - высший свет, сливки общества [3].

\section{5. Вешество}

Субъект находит свое лексическое воплощение в словах, передающих состояние вещества - воска, который имеет, согласно своей природе, мягкую физическую консистенцию.

- Cire molle - мягкий, податливый человек [3].

\section{6. Растение}

Семантический субъект метафорично обозначен фразеологизмами с негативной семантической окраской, в которых основным выражаемым понятием выступает тот или иной элемент или представитель флоры.

Например: graine (f) - зерно.

1) Mauvaise graine - ничтожный, порочный человек;

2) graine de crapule - подонки, шиана [3].

\section{7. Мебель}

Лексическое обозначение элементов мебели также нашло свое употребление во французских фразеологизмах для обозначения семантического субъекта в позитивной или негативном ключе.

а) Положительная оценка субъекта:

- C' est une bibliothèque vivante (ambulante) - эmo ходячая энциклопедия [3].

б) Негативная оценка субъекта:

- $C^{\prime}$ est une bibliothèque renversée - он много читал, давсе без толку [3].

\section{8. \Килише, помешение}

Понятия жилища, дома, его отдельных частей, лексически подразумевающее семантический субъект, представлено фразеологизмами, обладающими разной коннотацией:

а) отрицательная коннотация:

1. Château branlant - человек, нетвердо держащийся на ногах;

2. C'est un grenier à coups de poing - это задuра, которому всегда nonaдаem [3]. 
б) положительная коннотация:

- C'est un grenier à sel - это неистощимый остряк [3].

\section{9. Средства передвижения, транспорт}

Лексемам фразеологизмов, выражающих в своем первичном значении средства передвижения и их характеристики, в подавляющем случае свойственна негативная окраска, которой они наделяют и семантический субъект.

1. C' est une charette - это тугодум;

2. C' est une charette mal attelée - это неподходящая пара, каждый в свою сторону тянет [3].

\section{0. Емкость, источник}

Понятия емкость, источник, представленные во фразеологизмах субстантивом mine (f) в сочетании с означающими inépuisable и de savoir, характеризуют семантический субъект с разных аксиологических позиций.

а) Человек - это mine de savoir (d'érudition) - кладезь премудрости, знаний.

б) С другой стороны - это бездонная бочка - c'est une mine inépuisable [3].

\section{III. \Кивотные, птишы}

Животный мир является, как известно, зеркальным отражением мира людей, что, совершенно естественно, нашло свое отражение во фразеологическом тезаурусе французского языка. Солидную группировку составили фразеологизмы, содержащие лексемы, обозначающие представителей пернатого мира. Фразеологизмы дифференцированы разным коннотативным значением:

\section{1. Птицы}

Негативная коннотация:

1. Aigle blanc - главарь воровской шайки;

2. Ce n'est pas un aigle - он пороху не выдумал, он звезд с неба не хватает;

3. (реtite) оіe blanche - простушка, наивная девушка;

4. Coq de paroisse (du village) ирон. - первый парень на деревне;

5. Hirondelle de ponts - бродяга, кочующий под мостами;

6. L'oiseau en a dans l'aile - у него со здоровьем неважно, он на мели, у него подмоченная репутация [3].
Позитивная коннотация:

- Coq de paroisse (du village) ирон. - первый парень на деревне [3].

\section{2. ЖКивотные}

Представители фауны являются довольно частыми денотатами лексических единиц, выражающих семантический субъект - человека. Фразеологизмы с лексемами данной семантики имеют как позитивную (1), так и негативную (2) коннотативную окраску.

1. Cheval à la besogne (à l'ouvrage, au travail) - работяга;

2. Cheval qui n'a ni bouche ni éperon - своевольный человек [3].

\section{IV. Абстрактные понятия}

Следует отметить использование абстрактных лексем во фразеологических сочетаниях, служащих для выражения субъекта и характеристики его сущности.

Например:

1. Ame double - личемер, двоедушный;

2. Ame vivante - живая душа;

3. Ame de bouillie - размазня, бесхарактерный человек;

4. L'esprit court les rues - каждый воображает, что он остроумен [3].

Таким образом, анализ фактического материала продемонстрировал обширную номенклатуру французских фразеологических средств выражения семантического субъекта. В основе образования косвенного, фразеологического выражения субъекта лежат процессы метафоризации и метонимизации. Разнообразие средств выражения семантического субъекта объясняется, по нашему мнению, гибкостью языка и мышления человека, позволившему ему фразеологически обозначить субъект лексемами, выражающими предметы неживой природы, представителей флоры и фауны, части тела, абстрактные понятия и т.д.

Следует также отметить: французским фразеологизмам присуща не только негативная и позитивная коннотация, но и коннотация нейтральная.

\section{ЛИТЕРАТУРА}

1. Гак В.Г. Метафора: универсальное и специфическое // Метафора в языке и тексте. - М.: Наука, 1988. - С. 11-26.

2. Гак В.Г. Фразеологические единицы в свете асимметрии языкового знака // Языковые преобразования. М.: Школа «Языки русской культуры», 1998. $768 \mathrm{c}$.

3. Гак В.Г. Французско-русский фразеологический словарь / В.Г. Гак, И.А. Кунина и др. [под редакцией Я. М. Рецкера.] - М.: Государственное издательство иностранных и национальных словарей, 1963.- 1112 с.

4. Кунин А.В. Курс фразеологии современного английского языка.- М.: Высшая школа, Дубна, Изд. центр Феникс, 1996.- 381 с. 
5. Червоный А.М. Типология выражения концепта «ментальность»: монография. - Таганрог: Изд-во Таганрог. гос. пед. ин-та имени А.П. Чехова, 2013. - 144 с.

6. Червоный А.М. Семантический субъект и имплицитность // Современная наука: актуальные проблемы теории и практики: Гуманитарные науки. - 2020. № $6-2-$ C. 168-170.

7. Червоный А.М. Понятие «субъект» и его выражение в научном и обыденном дискурсе (на материале русского и французского языков) / А.М. Червоный // Сборник статей по итогам IV-й международной конференции «Язык и действительность». Научные чтения на кафедре романских языков им. В.Г. Гака». Том 5. - М.: Издательство «Спутник +», 2020. - С. 412- 417.

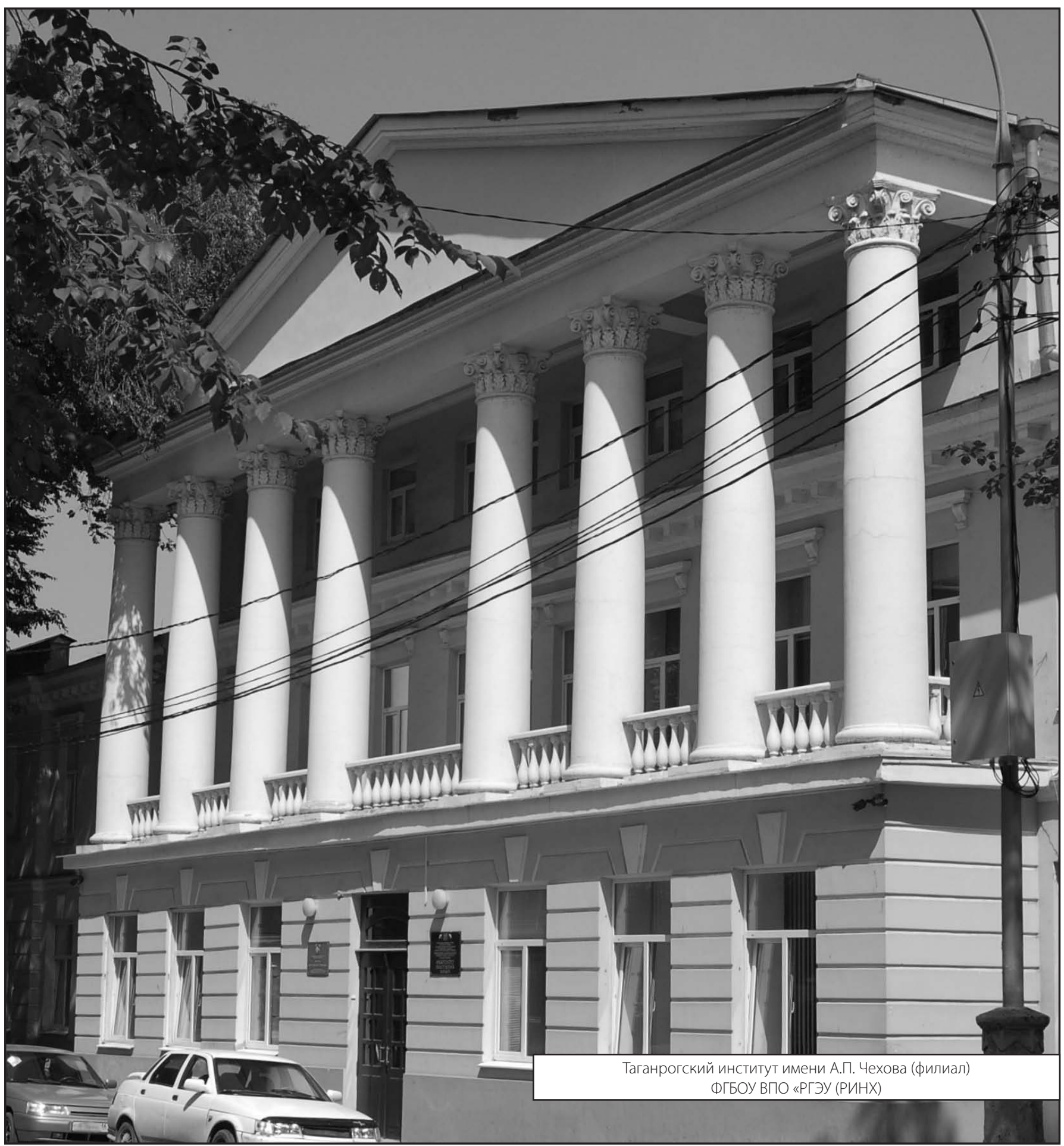

